\title{
Plasma digoxin concentration-its relation to digoxin dosage and clinical effects in patients with atrial fibrillation
}

\author{
Arne Redfors \\ From the Departments of Clinical Physiology and Internal Medicine and the \\ Division of Clinical Pharmacology, University Hospital, Lund, Sweden
}

With a modified, precise ${ }^{86} R b$ method plasma digoxin concentration was estimated in patients with atrial fibrillation. They received successively increasing digoxin doses until they began to develop symptoms of digitalis intoxication. The dosage was changed every 14 th day. A high correlation was found between digoxin dosage and plasma digoxin concentration. Patients who did not - develop symptoms of digitalis intoxication until at high doses showed a slower increase of plasma levels. At the first appearance of toxic symptoms 'steady state' values of about $\mathrm{I} \cdot 6 \mathrm{ng}$ digoxin $/ \mathrm{ml}$ were found. Excluding one divergent patient, a close inverse correlation was found between plasma digoxin concentration registered at $0.375 \mathrm{mg} /$ day and the 'optimal' doses or the toxic limit of the patients. With a plasma digoxin assay a prediction of an adequate digoxin dosage may thus be possible. Though a poor correlation was found between ventricular rate and plasma digoxin concentration there was a good relation between the clinical effects of the glycoside and the plasma concentration; the 'optimal' digoxin effect was obtained at a fairly constant level of digoxin in plasma.

In spite of extensive research no reliable method exists for the control of digitalis therapy. As there are great individual variations

- in tolerance to the drug it is often difficult to know if a patient really receives an 'optimal' dose of digitalis. Especially in some patients with rapid arrhythmias or uncharacteristic tiredness, it may be difficult to know whether more or less digitalis should be given. The high frequency of digitalis intoxications reported (Chung, 1969; Dubnow and Burchell, 1965; Hurwitz and Wade, 1969; Jørgensen $\checkmark$ and Sørensen, 1970; Shapiro et al., 1969) further emphasizes the need for controlling digitalis therapy by new objective methods.

One method may be the estimation of the glycoside concentration in plasma. In recent years, different principles for determination of digoxin in plasma have been developed (Brooker and Jelliffe, 1969; Jelliffe, 1966; Lowenstein, 1965; Smith, Butler, and Haber,

Received 28 May 1971.

1 This study was supported by grants from the Swedish - Medical Research Council the Swedish Pharmaceutical Manufacturers Association, the Swedish National Asso- ciation against Heart and Lung Diseases, and the Medical Faculty, the University of Lund.
1969); for a review, see Smith and Haber (1970). In 1966, Lowenstein and Corrill described a method based on the ability of cardiac glycosides to inhibit the uptake of ${ }^{86} \mathrm{Rb}$ in erythrocytes. After modification by Bertler and Redfors (1970b) this method got a good sensitivity and precision comparable to the radioimmunoassay recently published by Smith et al. (1969).

The limited results obtained so far with the above-mentioned methods, indicate that oral therapeutic doses of digoxin give plasma concentrations of only a few $\mathrm{ng} / \mathrm{ml}$ (Bertler and Redfors, 1970b; Binnion et al., 1969; Chamberlain et al., 1970; Evered, Chapman, and Hayter, 1970; Grahame-Smith and Everest, 1969; Lowenstein and Corrill, 1966; Smith et al., 1969). Despite the low plasma levels and the narrow therapeutic range of the glycoside, such methods may act as a guide to distinguish patients with from patients without digitalis intoxication (Chamberlain et al., 1970; Grahame-Smith and Everest, 1969; Redfors and Bertler, 1970; Smith et al., 1969).

In the present study on patients with atrial fibrillation the relation between dosage and plasma concentration of digoxin has been 
TABLE I Diagnoses and some clinical data on patients

\begin{tabular}{|c|c|c|c|c|c|c|}
\hline $\begin{array}{l}\text { Case } \\
\text { No. }\end{array}$ & Sex & $\begin{array}{l}\text { Age } \\
(y r)\end{array}$ & $\begin{array}{l}\text { Weight } \\
(\mathrm{kg})\end{array}$ & Diagnoses & $\begin{array}{l}\text { Clinical } \\
\text { grade }\end{array}$ & $\begin{array}{l}\text { Heart volume } \\
\left(\mathrm{ml} \text {-ml } / \mathrm{m}^{2} \text { body }\right. \\
\text { surface area })\end{array}$ \\
\hline 2 & $\mathbf{M}$ & 49 & 71 & $\begin{array}{l}\text { Mitral stenosis with mitral commissurotomy } \\
\text { + mitral insufficiency }\end{array}$ & III A & $1280-670$ \\
\hline 4 & $\mathbf{M}$ & 59 & 72 & Mitral insufficiency & II & I I $90-660$ \\
\hline 5 & $\mathbf{M}$ & 51 & 70 & Aortic stenosis + aortic insufficiency + mitral stenosis & III A & $1210-700$ \\
\hline 6 & $\mathbf{F}$ & 52 & 65 & Mitral stenosis & III A & $1120-700$ \\
\hline 7 & $\mathbf{F}$ & 62 & 63 & Mitral stenosis with mitral commissurotomy & III A & $1030-640$ \\
\hline 8 & $\mathbf{M}$ & 62 & 88 & Arteriosclerotic heart disease & III A & $1480-770$ \\
\hline 9 & F & $6 I$ & 76 & Hypertensive cardiovascular disease & I & $1050-570$ \\
\hline II & $\mathbf{M}$ & 56 & 87 & 'Idiopathic' atrial fibrillation & II & $1030-490$ \\
\hline 12 & $\mathbf{M}$ & 49 & 96 & 'Idiopathic' atrial fibrillation & I & $1010-460$ \\
\hline 13 & $\mathbf{M}$ & 68 & 78 & Hyperthyroidism + arteriosclerotic heart disease & III A (II) & $1330-670$ \\
\hline 14 & $\mathbf{M}$ & $6 r$ & 83 & Hypertensive cardiovascular disease & II (I) & $1090-550$ \\
\hline
\end{tabular}

Note: Clinical grades are classified according to the New York Heart Association as modified by Bishop and Wade (1963). In patients not previously digitalized clinical grades after digitalization are shown in parentheses.

examined. The plasma levels were related to the clinical effects of different digoxin doses changes in subjective symptoms, physical working capacity, and ventricular rate at rest and during exercise.

\section{Subjects and methods}

In a dose-response study II patients with atrial fibrillation were investigated. The diagnoses and some other clinical data are given in Table I. A more detailed presentation of the patient material has previously been published (Redfors, I971a).

All patients were given successively increasing digoxin doses, $0.125,0.25,0.375,0.50,0.75$, and $\mathrm{I} \cdot 00 \mathrm{mg} /$ day until symptoms or signs of digitalis intoxication appeared. The drug was given once a day in the morning. The dosage was unknown to the patients, and was changed every 14 th day. Tablets containing varying amounts of digoxin for the different treatment periods were specially prepared for the investigation. ${ }^{1}$ At the beginning of the study two patients were still undigitalized; the others had been given a stable maintenance dose of digoxin, mostly $0.375 \mathrm{mg} /$ day, for at least I4 days.

At the end of each 14 days' period of treatment, the patients were subjected to a careful physical examination including a thorough history. Electrocardiograms were recorded at rest and during an exercise tolerance test. Blood samples were drawn for analysis of plasma digoxin concentration, erythrocyte sedimentation rate, haemoglobin, and potassium in serum. The examinations were always carried out at the same time in the morning, starting about I $\frac{1}{2}$ hours after a light, standardized meal. The methods used to evaluate the different clinical effects of the digoxin treatment - changes in subjective symptoms, physical working capacity, and ventricular rate at rest and during exercise - have been described previously (Redfors, 1971a).

The following analyses were also performed in

1 AB Draco, Lund, Sweden. all patients: sodium, potassium, chloride, calcium, and magnesium in serum; protein bound iodine and $T_{3}$ resin test; liver function tests including bromsulphalein retention test; on three different days creatinine and urea nitrogen in serum and 24-hour creatinine clearances. The results have been previously reported (Redfors, 1971a) and are partly presented in Table 2.

Estimation of plasma digoxin concentration At the beginning of the investigation the original digoxin assay described by Lowenstein and Corrill (1966) was used. However, not until a systematic study of the method had been performed and certain modifications introduced, did the method gain the accuracy, precision, and sensitivity necessary to an investigation of this kind.

The digoxin assay has been described in detail elsewhere (Bertler and Redfors, 1970b). To study its reliability, each of 15 separate pools of plasma containing 0.5 to $\mathrm{r} .9 \mathrm{ng}$ digoxin $/ \mathrm{ml}$ was analysed in repeated triplicate determinations on 5 different days; between the triplicate determinations a standard deviation of $0.1 \mathrm{ng} / \mathrm{ml}$ was found. The lower limit of sensitivity was $0.3 \mathrm{ng} / \mathrm{ml}$ (3 SD) (Bertler and Redfors, 1970b).

TABLE 2 Some laboratory tests on patients

\begin{tabular}{|c|c|c|c|c|c|c|}
\hline $\begin{array}{l}\text { Case } \\
\text { No. }\end{array}$ & $\begin{array}{l}K / s \\
(m E q / l .)\end{array}$ & $\begin{array}{l}C a / s \\
(m E q / l .)\end{array}$ & $\begin{array}{l}M g / s \\
(m E q / l .)\end{array}$ & $\begin{array}{l}\text { Creat/s } \\
(\mathrm{mg} / \mathrm{IOO} \mathrm{ml})\end{array}$ & $\begin{array}{l}\text { Creatinine } \\
\text { clearance } \\
\text { (ml/min) }\end{array}$ & $\begin{array}{l}\text { Bromsulphalein } \\
\text { retention } \\
(\%)\end{array}$ \\
\hline 2 & $4 \cdot I$ & $5 \cdot 1$ & $1 \cdot 9$ & $I \cdot I$ & 85 & 46 \\
\hline 4 & 47 & $4 \cdot 8$ & $x \cdot 8$ & $\mathbf{I} \cdot \mathbf{I}$ & 90 & 9 \\
\hline 5 & $4 \cdot 3$ & $5 \cdot 2$ & $\mathrm{I} \cdot 7$ & 0.9 & 88 & 18 \\
\hline 6 & $4 \cdot 2$ & $4 \cdot 6$ & $I \cdot 9$ & 0.8 & 83 & Io \\
\hline 7 & 4.5 & 4.5 & $1 \cdot 9$ & 0.8 & 81 & 5 \\
\hline 8 & $4 \cdot 3$ & $4 \cdot 6$ & $\mathrm{I} \cdot 8$ & 0.9 & I4I & I6 \\
\hline 9 & 4.0 & $4 \cdot 8$ & $2 \cdot 0$ & 0.9 & 89 & 13 \\
\hline II & 4.5 & 4.5 & $2 \cdot I$ & $I \cdot I$ & 127 & 7 \\
\hline 12 & $4 \cdot 6$ & 4.8 & $2 \cdot 0$ & $I \cdot 2$ & 99 & 9 \\
\hline 13 & $4 \cdot 4$ & $4 \cdot 2$ & $2 \cdot 0$ & 0.9 & 97 & II \\
\hline I4 & $4 \cdot I$ & 46 & $1 \cdot 6$ & 0.8 & 132 & 6 \\
\hline
\end{tabular}

$\mathrm{K} / \mathrm{s}$, potassium in serum; $\mathrm{Ca}$, calcium; $\mathrm{Mg}$, magnesium; Creat, creatinine, etc., all it serum. 
In the present study the digoxin values given are means of 3 to 6 separate determinations, mostly performed on two different days. Complete digoxin analyses for all dose levels were obtained in 6 patients. The values of digoxin concentration referred to in most of this presentation, the 'steady state' values, are those obtained from the blood samples drawn 24 hours after the last dose of digoxin.

In order to study the 'absorption curves' of digoxin, blood samples were at every examination drawn also at 90 and 180 minutes after the administration of the daily maintenance dose of the period. Later on, plasma digoxin values were measured in all II patients before and 30,60, 90, 120 , and I80 minutes after administration of $0.375 \mathrm{mg}$ digoxin. The patients had received this dose once daily for at least 14 days.

\section{Results}

The plasma concentrations of digoxin regis- tered before administration of the daily maintenance dose on the last day of each period of treatment are presented in Fig. I. As can be seen, the plasma digoxin concentration increases linearly with increasing digoxin dose. The differences in plasma levels registered at adjacent digoxin doses were significant. At doses of 0.25 and $0.50 \mathrm{mg}$ dixogin/day, the mean plasma concentration was 0.7 and $1 \cdot 2$ $\mathrm{ng} / \mathrm{ml}$, respectively. The plasma concentration increased more slowly in patients who tolerated high dixogin doses; thus, the plasma level at toxicity, mean $\mathrm{I} \cdot 6 \mathrm{ng} / \mathrm{ml}$, became less scattered (range I.3-I.9). The correlation between plasma concentration and digoxin dos-

- age was highly significant $(r=0.91)$. The patients received increasing digoxin doses until minor symptoms of digitalis toxicity appeared. Most patients developed gastrointestinal symptoms, which rapidly disappeared when the dose again was reduced. At the end of the study an 'optimal' dose was decided for each patient (Redfors, I971a). This dose was chosen to afford a reasonable - margin of safety to the toxic limit (Table 3). The margin was somewhat modified by the individual degree of improvement observed during the study; thus, the dyspnoea and tiredness at exertion experienced by the patients during the different treatment periods were taken into consideration. The mean

- 'optimal' dose was for the II patients 0.43 $\mathrm{mg} /$ day, constituting nearly 70 per cent of the toxic dose, which on the average was 0.63 $\mathrm{mg} /$ day. At the 'optimal' dose a mean plasma digoxin concentration of $\mathrm{I} \cdot \mathrm{I} \mathrm{ng} / \mathrm{ml}$ was found (Table 3).

At the various digoxin doses a scattering of the digoxin values was observed in this as in other standardized examinations (Chamber-

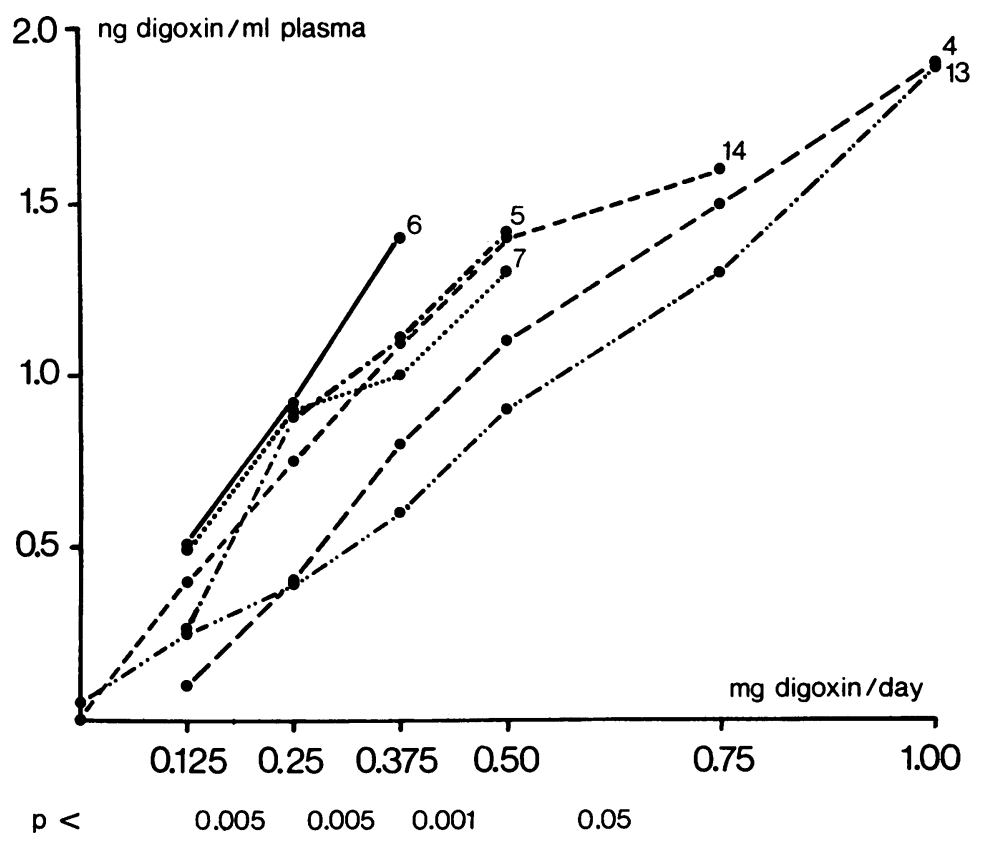

FIG. I Plasma digoxin concentrations at increasing digoxin maintenance doses. Figures at the end of the curves denote case numbers.

lain et al., 1970; Smith et al., 1969). In individual patients, however, the plasma levels seemed on a fixed dosage to be fairly stable from one time to another. In Io of the patients, plasma concentration was estimated on two different occasions with intervals of 2 to 9 months, when the patients had been similarly treated with $0.375 \mathrm{mg}$ digoxin/day for

TABLE 3 Maintenance digoxin doses (mg/day) and 'steady state' plasma digoxin concentration ( $\mathrm{ng} / \mathrm{ml})$ at 'optimal' treatment and at appearance of toxic manifestations

\begin{tabular}{|c|c|c|c|c|c|}
\hline \multirow{2}{*}{$\begin{array}{l}\text { Case } \\
\text { No. }\end{array}$} & \multicolumn{2}{|c|}{ 'Optimal' dosage } & \multicolumn{2}{|c|}{ Toxic dosage } & \multirow[t]{2}{*}{ Toxic symptoms } \\
\hline & $(m g / d a y)$ & $(n g / m l)$ & $(m g / d a y)$ & $(n g / m l)$ & \\
\hline 2 & 0.375 & $I \cdot 3$ & 0.50 & $I \cdot 6$ & Nausea, anorexia \\
\hline 4 & 0.50 & $\mathbf{I} \cdot \mathbf{I}$ & $I \cdot \infty$ & $\mathbf{I} \cdot 9$ & $\begin{array}{l}\text { Tiredness, lassitude, nausea, } \\
\text { and vomiting }\end{array}$ \\
\hline $\begin{array}{l}5 \\
6\end{array}$ & $\begin{array}{l}0.375 \\
0.25\end{array}$ & $\begin{array}{l}\mathbf{I} \cdot \mathbf{I} \\
0.9\end{array}$ & $\begin{array}{l}0.50 \\
0.375\end{array}$ & $\begin{array}{l}I \cdot 4 \\
I \cdot 4\end{array}$ & $\begin{array}{l}\text { Nausea, lassitude } \\
\text { Nausea, abdominal pain }\end{array}$ \\
\hline 7 & 0.375 & $1 \cdot 0$ & 0.50 & $1 \cdot 3$ & Nausea \\
\hline 8 & 0.50 & - & 0.75 & - & Nausea \\
\hline 9 & 0.50 & 一 & 0.625 & - & Nausea \\
\hline II & 0.375 & $\mathbf{I} \cdot \mathbf{2}$ & 0.50 & 一 & $\begin{array}{l}\text { Increasing dyspnoea, tired- } \\
\text { ness, lassitude, nausea, } \\
\text { and vomiting }\end{array}$ \\
\hline 12 & 0.25 & 0.5 & 0.375 & 0.7 & Anorexia, nausea, vomiting \\
\hline 13 & 0.75 & $1 \cdot 3$ & $I \cdot \infty$ & $I \cdot 9$ & Nausea, abdominal discomfort \\
\hline 14 & 0.50 & $\mathrm{I} \cdot 4$ & 0.75 & $\mathrm{I} \cdot 6$ & Nausea, vomiting \\
\hline
\end{tabular}


at least 14 days. The average difference between the two estimations in samples taken before the daily dose was $0.0 \pm 0.2 \mathrm{ng} / \mathrm{ml}$ $( \pm S D)$. The mean plasma values from these occasions ranged from 0.6 to $\mathrm{r} \cdot 4 \mathrm{ng} / \mathrm{ml}$. These varying plasma levels were, if Case I2 was excluded, significantly negatively correlated to the total amount of digoxin administered from the beginning of the $0.125 \mathrm{mg}$ period to appearance of the toxic symptoms (Fig. 2), that is to the toxic limit, in all patients estimated in the same, standardized way. A similar high correlation $(r=-0.83)$ was found simply by plotting the plasma values against the toxic doses. The mean plasma levels at $0.375 \mathrm{mg}$ digoxin/day were also significantly correlated to the 'optimal' dosage (Fig. 3). High plasma values thus indicated that the patients had reached or were near the toxic limit, and low plasma values indicated that the dose could be further increased.

That occasional patients may show a divergent reaction to the glycoside was in this study exemplified by one man (Case 12) weighing $96 \mathrm{~kg}$, who developed toxic symptoms at a plasma level of only $0.7 \mathrm{ng} / \mathrm{ml}$, when he had received $0.375 \mathrm{mg}$ digoxin/day for a few days (Table 3). His electrolytes were normal as well as his renal, liver, and thyroid function tests (Table 2). At the toxic dosage he also showed a divergent response to exercise with very rapid ventricular rate at low work loads in spite of a good physical working capacity (Redfors, I97Ib). It may be mentioned that he had always been very prone to develop motion sickness.

Plasma digoxin values, registered 90 and I 80 minutes after administration of the different digoxin maintenance doses, were about 3 and 2 times as high, respectively, as the plasma levels before the intake of the daily dose. Means and standard deviations of the values registered at the different digoxin doses are given in Table 4. The mean plasma concentration was $4.2 \mathrm{ng} / \mathrm{ml} 90$ minutes after administration of the digoxin doses which gave toxic symptoms.

The variability of plasma digoxin concentration in the first hours after oral administration of $0.375 \mathrm{mg}$ digoxin is further presented in Table 5. Great differences were found between patients regarding both plasma levels and the profiles of the curves (Fig. 4). These characteristic profiles of the individual plasma digoxin curves were at repeated examinations essentially the same.

In the present study the subjective tiredness and dyspnoea decreased when the digoxin dosage was increased from the insufficient dose of $0.125 \mathrm{mg} /$ day (Redfors, 1971a).

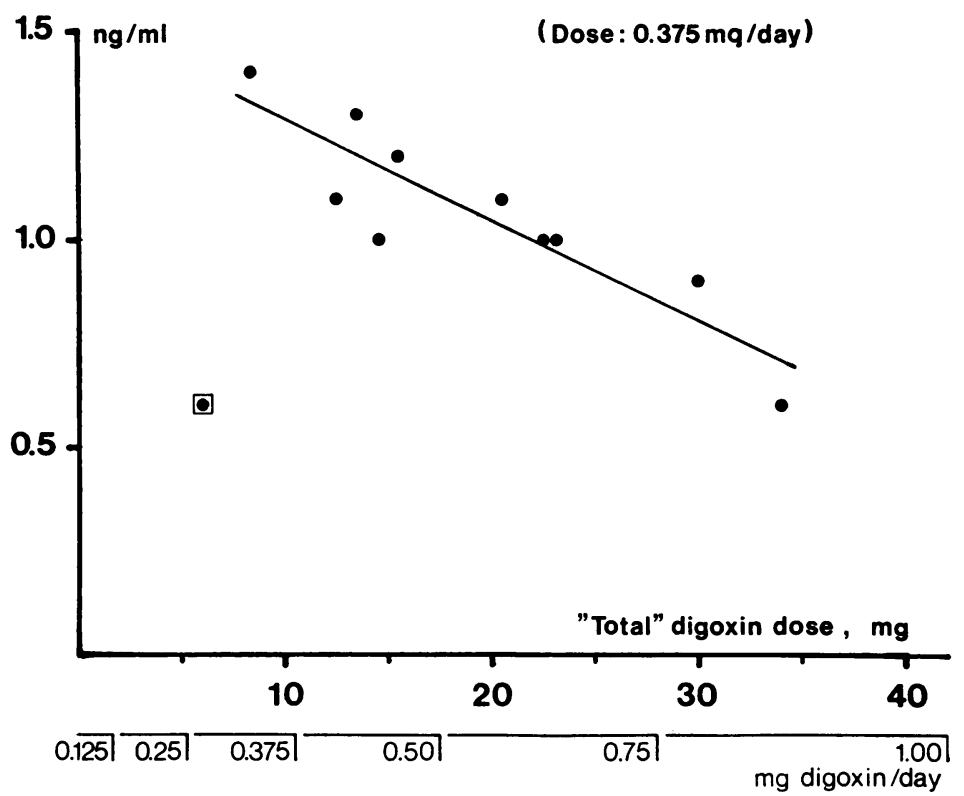

FIG. 2 'Steady state' plasma digoxin concentration at $0.375 \mathrm{mg}$ daily in relation to the total amount of digoxin administered to the patients up to the appearance of toxicity. The daily dosage during the different treatment periods is indicated below. $\square=$ Case $I 2$ with a divergent reaction to the glycoside. For the other ro patients $r=0.89 ; P<0.001$.

FIG. 3 The correlation between the 'steady state' plasma digoxin concentration at a maintenance dose of $0.375 \mathrm{mg} /$ day and the 'optimal' doses of the patients. $\Delta=$ the divergent Case 12. For the other 10 patients $r=0.91 ; P<0.001$. Compare Fig. 2.

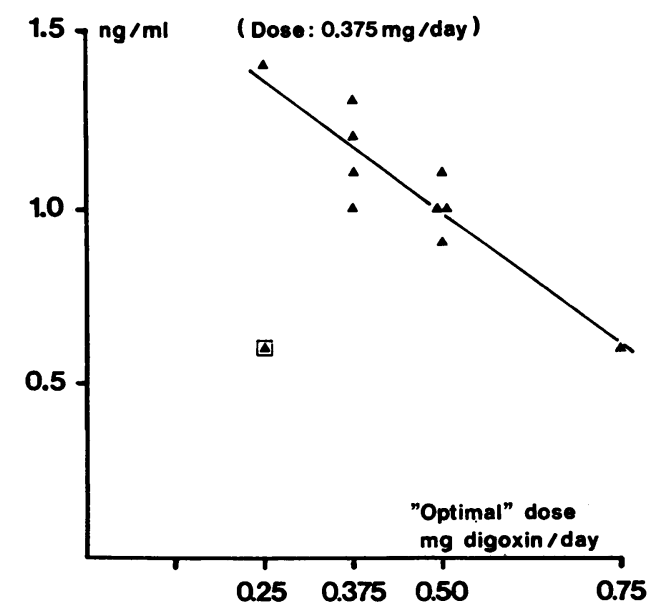


There were great individual differences in the response to the treatment, but the mean improvement was well related to the dosage up to an 'optimal' dose level, where the doseresponse curve levelled off. A similar relation was found between the physical working capacity estimated at exercise tests and the digoxin dosage (Redfors, I97Ib). The plasma digoxin concentration increased fairly linearly with increasing doses up to the toxic limit (Fig. I). The correlation between dosage and plasma levels was much better than it was between the dosage and the subjective symptoms or physical working capacity. These two facts may 'explain' that there was not always a good correlation in individual cases between changes of plasma digoxin levels and the changes of subjective improvement on each dose step.

Ventricular rate at rest and during exercise, measured at strictly standardized conditions, decreased significantly at increasing digoxin dosage (Redfors, 197Ib). A corresponding slowing of ventricular rate was found at increasing plasma digoxin concentrations (Fig. 5). The great differences in ventricular rate observed between patients when they were treated with the same digoxin doses gave in the whole material a poor correlation between ventricular rate and plasma digoxin concen-

FIG. 4 Plasma digoxin concentration before and 30,60, 90, 120, and 180 minutes after

- oral administration of a maintenance dose of $0.375 \mathrm{mg}$ digoxin.

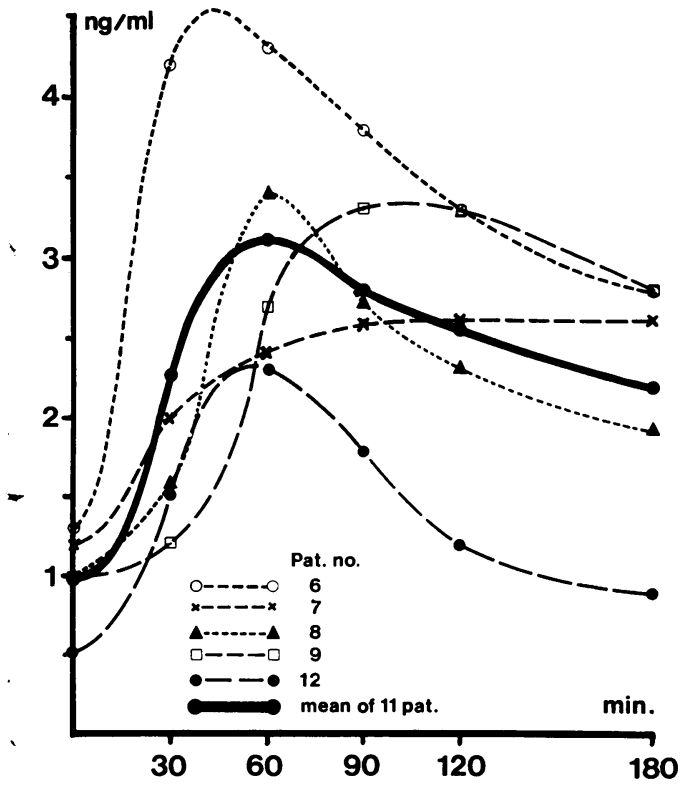

TABLE 4 Plasma digoxin concentration (mean $\pm S D$ ) before and 90 and 180 minutes after administration of the daily digoxin maintenance doses. At I.00 mg/day only one patient was given this dose at day of examination

\begin{tabular}{|c|c|c|c|c|}
\hline \multirow{3}{*}{$\begin{array}{l}\text { Digoxin dose } \\
\text { (mg/day) }\end{array}$} & \multirow{3}{*}{$\begin{array}{l}\text { No. of } \\
\text { patients }\end{array}$} & \multicolumn{3}{|c|}{ Plasma digoxin concentration $(\mathrm{ng} / \mathrm{ml})$} \\
\hline & & \multirow[t]{2}{*}{ Before } & \multicolumn{2}{|l|}{ After } \\
\hline & & & $90 \min$ & $I 80 \min$ \\
\hline 0.125 & 6 & $0.33 \pm 0.16$ & $0.93 \pm 0.37$ & $0.68 \pm 0.27$ \\
\hline 0.25 & 6 & $0.71 \pm 0.24$ & $2.05 \pm 0.63$ & $1.02 \pm 0.37$ \\
\hline 0.375 & 6 & $1 \cdot 00 \pm 0.27$ & $2.46 \pm 0.75$ & $1.94 \pm 0.52$ \\
\hline 0.50 & 5 & $I \cdot 22 \pm 0.22$ & $3.41 \pm 0.40$ & $2.40 \pm 0.42$ \\
\hline 0.75 & 3 & $I \cdot 47 \pm 0.15$ & $3.97 \pm 0.96$ & $2.98 \pm 0.44$ \\
\hline $\mathbf{1} \cdot \infty$ & $2(I)$ & $I .90 \pm 0.00$ & 4.9 & $3 \cdot 4$ \\
\hline 'Optimal' dose & 6 & $I \cdot I 3 \pm 0 \cdot 18$ & $2.93 \pm 0.79$ & $2 \cdot 19 \pm 0.84$ \\
\hline Toxic dose & 6 & $I \cdot 58 \pm 0.26$ & $4 \cdot 20 \pm 0.71$ & $2.91 \pm 0.45$ \\
\hline
\end{tabular}

tration. Also, at the 'optimal' dosage the ventricular rate was scattered, especially the rate at middle and high work loads. The plasma digoxin levels at these 'optimal' doses were, on the contrary, fairly well gathered as is seen in Fig. 5.

\section{Discussion}

The main problem in estimation of digoxin in plasma has been the very low concentrations of the glycoside due to its rapid disappearance from plasma. After a daily administration for seven days of $0.5 \mathrm{mg}$ tritiated digoxin, Marcus et al. (1966) registered a radioactivity corresponding to a digoxin concentration of $I \cdot I \pm$ $0.3 \mathrm{ng} / \mathrm{ml}$ of blood (mean \pm SD) in undigitalized volunteers. Samples were drawn 24 hours after the last dose given. With a method based

TABLE 5 Plasma digoxin concentration before and 30, 60, 90, I20, and 180 minutes after administration of a daily maintenance dose of $0.375 \mathrm{mg}$ digoxin

\begin{tabular}{|c|c|c|c|c|c|c|}
\hline \multirow[t]{2}{*}{ Case No. } & \multirow[t]{2}{*}{ Before } & \multicolumn{5}{|c|}{ After (min) } \\
\hline & & 30 & 60 & 90 & I 20 & 180 \\
\hline 2 & $\mathbf{I} \cdot 3$ & $2 \cdot 5$ & $3 \cdot 3$ & $3 \cdot 3$ & $2 \cdot 7$ & $2 \cdot 5$ \\
\hline 4 & 0.9 & $3 \cdot 4$ & $3 \cdot 3$ & $2 \cdot 6$ & $2 \cdot 5$ & $2 \cdot 0$ \\
\hline 5 & 0.8 & $2 \cdot 9$ & $3 \cdot 6$ & $2 \cdot 5$ & $2 \cdot 3$ & $\mathrm{I} \cdot 8$ \\
\hline 6 & $\mathbf{I} \cdot 3$ & $4 \cdot 2$ & $4 \cdot 3$ & $3 \cdot 8$ & $3 \cdot 3$ & $2 \cdot 8$ \\
\hline 7 & $I \cdot 2$ & $2 \cdot 0$ & $2 \cdot 4$ & $2 \cdot 5$ & $2 \cdot 5$ & $2 \cdot 6$ \\
\hline 8 & $\mathbf{I} \cdot 0$ & $I \cdot 5$ & $3 \cdot 4$ & $2 \cdot 7$ & $2 \cdot 3$ & $I \cdot 9$ \\
\hline 9 & $I \cdot O$ & $I \cdot 2$ & $2 \cdot 7$ & $3 \cdot 3$ & $3 \cdot 3$ & $2 \cdot 8$ \\
\hline I I & $\mathbf{I} \cdot \mathbf{I}$ & $I \cdot 3$ & $2 \cdot 6$ & $2 \cdot 6$ & $2 \cdot 2$ & $I \cdot 9$ \\
\hline 12 & 0.5 & $1 \cdot 5$ & $2 \cdot 3$ & $I \cdot 8$ & $1 \cdot 2$ & 0.9 \\
\hline I3 & 0.8 & $3 \cdot I$ & $3 \cdot 8$ & $3 \cdot 2$ & $2 \cdot 9$ & $2 \cdot 4$ \\
\hline 14 & $\mathbf{I} \cdot \mathbf{I}$ & $1 \cdot 6$ & $2 \cdot 2$ & $3 \cdot 0$ & $3 \cdot 2$ & $2 \cdot 8$ \\
\hline Mean $\pm S D$ & $I \cdot 0 \pm 0.2$ & $2 \cdot 3 \pm I \cdot 0$ & $3 \cdot 1 \pm 0.7$ & $2.8 \pm 0.5$ & $2.6 \pm 0.6$ & $2.2 \pm 0.6$ \\
\hline
\end{tabular}


on the ability of digoxin to inhibit the ${ }^{86} \mathrm{Rb}$ uptake in erythrocytes, originally described by Lowenstein and Corrill (1966), GrahameSmith and Everest (1969) found values of $2.4 \mathrm{ng} / \mathrm{ml}(0.8-4.5)$ in patients without toxic symptoms, treated with $0.25 \mathrm{mg}$ digoxin/day or more.

The modified ${ }^{86} \mathrm{Rb}$ method used in the present study had such a good precision that it was possible to measure small but significant differences in plasma concentration between doses which differed only by $0.125 \mathrm{mg} /$ day. It is difficult to compare the results with those of Grahame-Smith and Everest (1969) as these authors did not define the time between digoxin administration and plasma sampling, neither were the doses more exactly specified. Smith et al. (1969) and Chamberlain et al. (1970), both using a radioimmunoassay, at different digoxin doses found plasma values which were throughout $0.2-0.4 \mathrm{ng} / \mathrm{ml}$ higher than the concentrations registered at corresponding doses in the present study (Table 4). These slightly higher values may, however, be explained by the shorter intervals used between last dose administered and plasma sampling. Therefore, plasma digoxin levels found in the present study were in very good agreement with the results obtained by the radioimmunoassay. The values were also in accordance with the results obtained by Marcus et al. (1966).

Relation between digoxin dosage, plasma digoxin concentration, and tolerance to drug In previous studies (Chamberlain et al., 1970; Smith et al., 1969) plasma samples for digoxin assay at different doses were drawn from different patient groups. In the present investigation the same patients were studied at the different dose levels. The correlation found between plasma concentration and the daily digoxin dose was highly significant. It was interesting to note that patients who did not develop symptoms of digitalis intoxication until at high digoxin doses showed a slower increase of plasma digoxin concentration than patients who became intoxicated at low doses. Thus, the plasma levels with one exception at the toxic doses were well gathered despite a great individual difference in tolerance to the drug. This fact may contribute to the fairly small overlapping found in other patient material between plasma levels registered in patients with and without symptoms or signs of digitalis intoxication (Chamberlain et al., 1970; Redfors and Bertler, 1970; Smith et al., 1969). It must, however, be stressed that it is highly essential to define the interval between last dose given
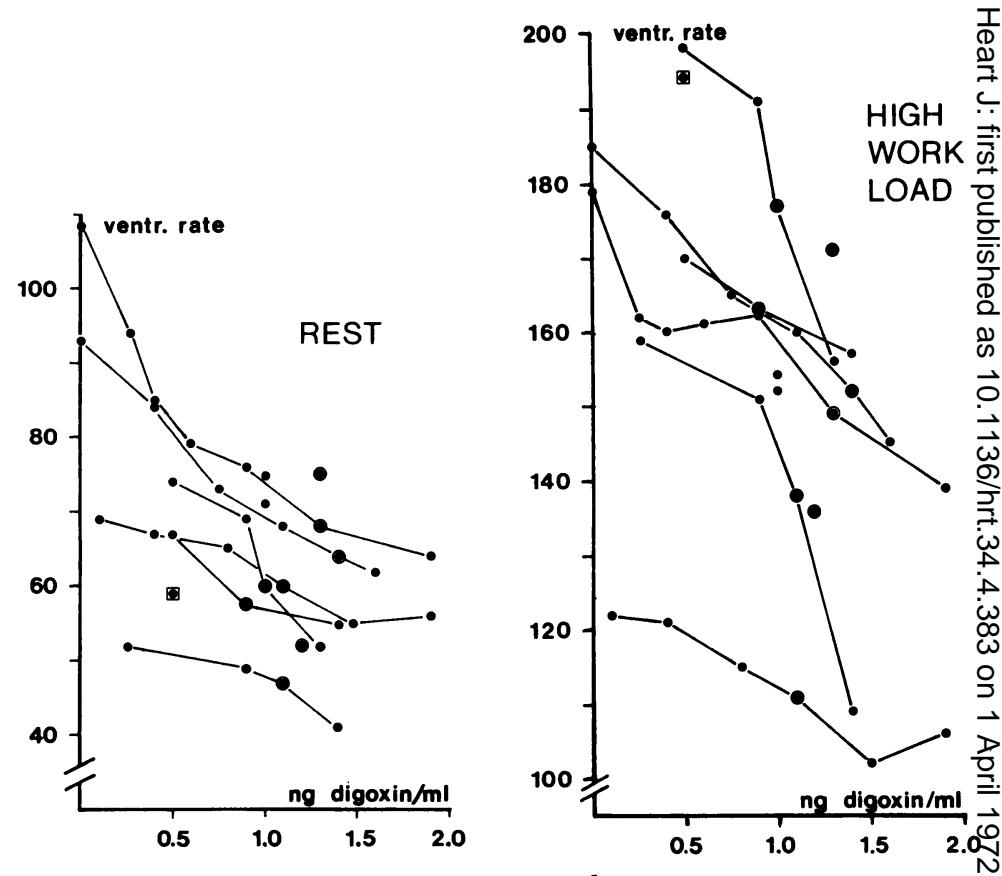

$a$

$b$

FIG. 5 Ventricular rate at rest and at high work loads (that is the highest load managed by the patient for 6 minutes in all treatment periods) at increasing plasma levels of digoxin. The dots on the curves denote measurements at the different doses used in the study. $\mathrm{Q}=$ 'optimal' dose of the divergent Case 12. $\mathrm{O}=$ 'optimal' doses of the other patients.

and plasma sampling and to relate obtained values to 'normal values' for the specific interval used (Bertler and Redfors, 1970a). The increase in plasma digoxin levels in the first hours after oral administration of the glycoside was in the present study of the same magnitude as that found by Marcus et al. (1966) and greater than that recently reported by Evered $e t$ al. (1970). The individual variations in the shape of the plasma concentration curves (Fig. 4) indicate that a fairly long interval is preferable. In order to get a relative 'steady state' condition, which would probably most reliably reflect the pharmacologically active digoxin concentration in the myocardium, an interval of 24 hours was chosen between the last dose and blood sampling. This routine also gave a good reproducibility between days.

Plasma digoxin concentrations at a certain dosage $(0.375 \mathrm{mg} /$ day $)$ were significantly negatively correlated both to the 'optimal' dosage and the toxic limit of the patients, ex- 
pressed as the total amount of digoxin administered from the $0.125 \mathrm{mg}$ period until symptoms of toxicity developed. Thus, there may be a possibility to predict an adequate digoxin dosage for a patient from determinations of 'steady state' plasma digoxin concentrations at lower digoxin doses. Such an application of the method would be of great clinical value, and may help to prevent digitalis intoxication, which seems to increase in frequency (Dubnow and Burchell, 1965; Hurwitz and Wade, 1969; Jørgensen and Sørensen, 1970). That a similar prediction from ventricular rate at rest or exercise is very inaccurate has previously been shown in this study (Redfors, 197 Ib). The small changes in plasma levels found in repeated examinations performed several months apart in patients on a fixed digoxin dosage favour the prediction possibility from plasma digoxin levels. - To what extent an altered electrolyte balance, or other factors known to influence the sensitivity to the drug - for review see Surawicz and Mortelmans (1969) - may upset such a prediction will be a matter for further studies. The limited degree of overlapping between toxic and non-toxic plasma levels in samples taken from patients in the clinical routine may indicate that such modifying factors are mostly not of decisive importance. Difficulties may, however, be presented by occasional patients, who for no obvious reasons may have a quite divergent 'sensitivity' to the glycoside. This was illustrated by one patient in the present study. How common such cases are is not

- known, as the toxic limit or the adequacy of the digitalis treatment has not previously been defined in patients in whom the plasma concentration of digitalis has been measured.

The individual tolerance to digitalis was in this study at least partly shown to be due to factors that determine the concentration of digoxin in plasma - absorption, tissue distribution, metabolism, or excretion. It has

t previously not been possible to analyse the significance of the absorption of the glycoside, without administration of isotopically labelled digitalis preparations. Though the variations of the plasma digoxin concentration registered during the first hours after dose administration may depend on other factors, it seems

- most natural to assume that these individual variations are due to relatively pronounced differences in the ability of drug absorption (Bertler and Redfors, I970a; Wilson, 1969). To study this problem more complete kinetic studies, with estimation of the digoxin content in faeces, urine, and tissues are now in pro- gress using the present ${ }^{86} \mathrm{Rb}$ method.

Reduced renal function is known to modify plasma digoxin levels and tolerance to digitalis (Doherty, 1968; Jelliffe, 1968). In the present study the renal function of all patients was mainly within normal limits, which may explain that the correlations between the creatinine and digoxin clearances and the toxic dosages were only probably significant. An average of about 60 per cent of the daily maintenance dose of $0.375 \mathrm{mg}$ was found in the urine. The relevance in the present patient material of some other factors, which can affect the individual tolerance to digitalis, is discussed separately (Redfors, 1971a).

Plasma digoxin concentration at digitalis intoxication There are no generally agreed criteria for digitalis toxicity; therapeutic and toxic effects merge one into the other. In this study the toxic dosage was defined as the dose at which increasing symptoms indicating toxicity developed. Also, transient nausea one hour or more after an oral dose of digoxin was accepted as a toxic manifestation if it returned from one day to another with increasing severity and then disappeared when the dosage was reduced. Other definitions could be used, and another, somewhat higher limit of toxicity would presumably have been found if, for instance, digoxin had been given in divided doses and not in one daily dose. Most important in this study was, however, that all the patients were treated and judged in a strictly standardized way and were thus comparable to each other.

The 'steady state' plasma digoxin concentration at toxicity was lower in this study than otherwise reported for patients with digitalis intoxication (Chamberlain et al., 1970; Redfors and Bertler, 1970; Smith et al., 1969). In these patients mean values of 2.4-3.3 $\mathrm{ng} / \mathrm{ml}$ were found. The discrepancy may, at least partly, be explained by the fact that the plasma digoxin concentration in the carefully controlled patients of the present study was estimated at an earlier stage of the intoxication than is usually possible in toxic patients found in the clinical routine.

Cardiac arrhythmias frequently occur in patients suffering from digitalis intoxication (Chung, 1969; Jørgensen and Sørensen, 1970; Shrager, 1957); in the present investigation, however, only few cardiac signs of digitalis intoxication were seen (Redfors, I97 Ib). The relations between the plasma and myocardial digoxin concentrations and the digitalis induced arrhythmias are insufficiently known (Marcus, 1969; Smith and Haber, 1970). Changes in inter alia, potassium and sodium levels have in animals been shown to influence the digoxin content of the myocardium (Cohn, 
Kleiger, and Harrison, 1967; Harrison and Wakim, 1969; Marcus, Kapadia, and Goldsmith, 1969). Only a part of the myocardial glycoside is, however, supposed to be immediately involved in the development of the pharmacological effects of the drug (Lüllmann and van Zwieten, 1969). As digoxin is only little bound to plasma protein the 'steady state' concentration of digoxin in plasma may reflect this pharmacologically 'active' myocardial digoxin fraction, which probably, together with the state of myocardium, is of importance for the development of cardiotoxic manifestations. Plasma digoxin assay may therefore give information of prognostic value in the diagnosis of digitalis intoxications.

The toxic symptoms were in the present study mainly gastrointestinal and appeared in most patients simultaneously with the plasma peak concentration, that is about one hour after administration of the daily dose. The plasma peak levels, mostly about $4-5 \mathrm{ng} / \mathrm{ml}$, thus often seemed to provoke the extracardiac toxic symptoms. In one patient (Case 14) nausea and vomiting developed before the plasma concentration had significantly increased. This may indicate that toxic gastrointestinal symptoms can sometimes be provoked by a peripheral mechanism.

\section{Plasma digoxin concentration and clini-} cal effects Largely unexplored, as yet, is the relation between plasma digoxin levels of chronically administered glycosides and the clinical effects of the drug. Chamberlain et al. (1970) recently reported a poor correlation between ventricular rate and plasma levels of digoxin in patients with atrial fibrillation. Patients with rates lower than $85 / \mathrm{min}$ at rest had a mean plasma digoxin level of $1 \cdot 6 \pm 0 \cdot 7$ $\mathrm{ng} / \mathrm{ml}$ as compared to a mean of $\mathrm{I} \cdot 2 \pm 0.7$ $\mathrm{ng} / \mathrm{ml}$ for patients with higher rates. In investigations where an 'optimal' dose or the toxic limit of each patient has not been tested, it is, however, impossible to know to what extent varying plasma values or varying ventricular rates at a certain dosage are due to differences in the adequacy of digitalis treatment. Also, in the present investigation a poor correlation between ventricular rate and plasma digoxin concentration was found from all the single values. This was shown, however, mainly to be due to the great individual variation in ventricular rate and could not be taken as proof of a poor correlation between plasma concentration and clinical response. On the contrary, in the individual patients this relation was good.

Great individual differences were seen in the effect of digoxin on dyspnoea and tiredness and on the physical working capacity (Redfors, 1971a). Some patients were at 'optimal' doses considerably improved, whereas others were not. Accordingly, there were in different patients varying relations between plasma digoxin concentration and these clinical effects. The fact that plasma digoxin levels at the 'optimal' doses were fairly well gathered indicates, however, that there is actually a good relation also between plasma concentration and these clinical effects of the glycoside. This may be in agreement with the above-mentioned statements of Lüllmann and van Zwieten (1969) and gives further support to the view stated by, among others, Doherty (1968) and Marcus (1969) that estimation of digoxin in plasma should be of clinical value.

The author wishes to thank Mrs. RosendalHelgesen and Mrs. Majken Leijonhufvud for skilful technical assistance.

\section{References}

Bertler, A., and Redfors, A. (I970a). New ways with digoxin. Lancet, $1,787$.

Bertler, Å., and Redfors, A. (1970b). An improved method of estimating digoxin in human plasma. Clinical Pharmacology and Therapeutics, 11, 665.

Binnion, P. F., Morgan, L. M., Stevenson, H. M., and Fletcher, E. (1969). Plasma and myocardial digoxin concentrations in patients on oral therapy. British Heart fournal, 31, 636.

Bishop, J. M., and Wade, O. L. (1963). Relationships between cardiac output and rhythm, pulmonary vascular pressures and disability in mitral stenosis. Clinical Science, 24, 39I.

Brooker, G., and Jelliffe, R. W. (1969). Determination of serum digoxin by enzymatic isotopic displacement of $\mathrm{H}^{3}$ digoxin and Na-K ATPase. Federation Proceedings, 28, 608.

Chamberlain, D. A., White, R. J., Howard, M. R., and Smith, T. W. (1970). Plasma digoxin concentrations in patients with atrial fibrillation. British Medical fournal, 3, 429.

Chung, E. K. (1969). Digitalis Intoxication. Excerpta Medica Foundation, Amsterdam.

Cohn, K. E., Kleiger, R. E., and Harrison, D. C. (1967). Influence of potassium depletion on myocardial concentration of tritiated digoxin. Circulation Research, 20, 473.

Doherty, J. E. (1968). The clinical pharmacology of digitalis glycosides: a review. American fournal of the Medical Sciences, 225, 382.

Dubnow, M. H., and Burchell, H. B. (1965). A comparison of digitalis intoxication in two separate periods. Annals of Internal Medicine, 62, 956.

EveredDD. C., Chapman, C., and Hayter, C. J. (1970). Measurement of plasma digoxin concentration by radioimmunoassay. British Medical fournal, 3, 427.

Grahame-Smith, D. G., and Everest, M. S. (I969). Measurement of digoxin in plasma and its use in diagnosis of digoxin intoxication. British Medical fournal, $\mathbf{x}, 286$.

Harrison, C. E., and Wakim, K. G. (1969). Inhibition of binding of tritiated digoxin to myocardium by sodium depletion in dogs. Circulation Research, 24, 263. 
Hurwitz, N., and Wade, O. L. (1969). Intensive hospital monitoring of adverse reactions to drugs. British Medical fournal, $\mathbf{1}, 531$.

Jelliffe, R. W. (1966). A chemical determination of urinary digitoxin and digoxin in man. Fournal of Laboratory and Clinical Medicine, 67, 694.

Jelliffe, R. W. (1968). An improved method of digoxin therapy. Annals of Internal Medicine, 69, 703.

Jørgensen, A. W., and Sørensen, O. H. (1970). Digitalis intoxication. Acta Medica Scandinavica, 188, I79.

Lowenstein, J. M. (1965). A method for measuring plasma levels of digitalis glycosides. Circulation, 3I, 228.

Lowenstein, J. M., and Corrill, E. M. (1966). An improved method for measuring plasma and tissue concentrations of digitalis glycosides. Fournal of Laboratory and Clinical Medicine, 67, 1048.

Lüllmann, H., and van Zwieten, P. A. (1969). The kinetic behaviour of cardiac glycosides in vivo, measured by isotope techniques. Fournal of Pharmacy and Pharmacology, 21, I.

Marcus, F. I. (1969). Editorial. Assay of digitalis concentrations in blood. New England fournal of Medicine, 281, 1242.

Marcus, F. I., Burkhalter, L., Cuccia, C., Pavlovich, J., and Kapadia, G. G. (1966). Administration of tritiated digoxin with and without a loading dose. Circulation, 34, 865.

Marcus, F. I., Kapadia, G. G., and Goldsmith, C. (1969). Alteration of the body distribution of tritiated digoxin by acute hyperkalemia in the dog. fournal of Pharmacology and Experimental Therapeutics, 165, 136.

Redfors, A. (I971a). The effect of different digoxin doses on subjective symptoms and physical working capacity in patients with atrial fibrillation. Acta Medica Scandinavica, 190, 307.

Redfors, A. (197Ib). Digoxin dosage and ventricular rate at rest and exercise in patients with atrial fibrillation. Acta Medica Scandinavica, 190, 321.

Redfors, A., and Bertler, $\AA$. (1970). Estimation of plasma digoxin and its diagnostic use in suspected digitalis induced arrhythmias. In Symposium on Cardiac Arrhythmias, Elsinore, Denmark 1970, p. 601 . Ed. by E. Sandoe, E. Flensted-Jensen, and K. H. Oleson. Astra, Södertälje, Sweden.

Shapiro, S., Slone, D., Lewis, G. P., and Jick, H. (1969). The epidemiology of digoxin. Fournal of Chronic Diseases, 22, 36r.

Shrager, M. W. (1957). Digitalis intoxication. Archives of Internal Medicine, 100, 881.

Smith, T. W., Butler, V. P., and Haber, E. (1969). Determination of therapeutic and toxic serum digoxin concentrations by radioimmunoassay. New England fournal of Medicine, 281, 1212.

Smith, T. W., and Haber, E. (1970). Editorial. Current techniques for serum or plasma digitalis assay and their potential clinical application. American Fournal of the Medical Sciences, 259, 301.

Surawicz, B., and Mortelmans, S. (I969). Factors affecting individual tolerance to digitalis. In Digitalis, p. 127. Ed. by C. Fisch and B. Surawicz. Grune and Stratton, New York.

Wilson, W. S. (1969). Newer concepts regarding digitalis therapy. Medical Clinics of North America, 53, I279.

Requests for reprints to Dr. Arne Redfors, Medicinska kliniken A, Lasarettet, S-22I 85 Lund, Sweden. 